\title{
PARASITIC INFESTATIONS AND INFECTIONS IN MARINE FISH (ACTINOPTERYGII: LUTJANIDAE AND MULLIDAE) MARKETED IN BRAZIL - AN ANIMAL AND HUMAN HEALTH ISSUE
}
(Infestações e infecções parasitárias em peixes marinhos (Actinopterygii: Lutjanidae e Mullidae) comercializados no Brasil - uma questão de saúde animal e humana)

Ana Paula dos Santos Ferreira ${ }^{1}$, Nicolas Tarmeño Rojas ${ }^{1}$, Sirlei da Costa Queiroz ${ }^{1}$, Letícia Gabriela Poblete Vidal ${ }^{2}$, Francinete Torres Barreiro da Fonseca ${ }^{1}$, Valdemiro Amaro da Silva Júnior ${ }^{1}$, José Luis Luque $^{2}$, Jaqueline Bianque Oliveira ${ }^{1}$

${ }^{1}$ Universidade Federal Rural de Pernambuco, Recife, PE, Brasil; ${ }^{2}$ Universidade Federal Rural do Rio de Janeiro, Seropédica, RJ, Brasil.

*Corresponding author: jaqueline.boliveira@ufrpe.br

ABSTRACT - The objective of this study was to identify the parasitic fauna, the impact of the parasite-host relationship and the potential risk of transmission of zoonotic parasites in fish marketed in the Metropolitan Region of Recife (Northeastern of Brazil). Ectoparasites and endoparasites were collected in Pseudupeneus maculatus $(\mathrm{n}=34)$, Lutjanus synagris $(\mathrm{n}=23)$, and Ocyurus chrysurus $(\mathrm{n}=20)$. Organs and/or tissues with and without parasites were processed by routine histological techniques. Overall, 43 (55.8\%) specimens were parasitized by: Rocinela signata, Lernanthropus sp.; Lernaeolophus sultanus, Goussia sp.; Haliotrema sp.; Raphidascaris (/chthyascaris) sp.; Cucullanus sp.; larvae of Pseudoterranova sp., Contracaecum sp., Anisakis sp., and Trypanorhyncha. Macroscopic and/or histological alterations were associated with Lernantrhopus sp. (gills) and Pseudoterranova sp. (liver) in $O$. chrysurus, $R$. signata (gills) in P. maculatus, and Lernaeolophus sultanus (maxilla) of L. synagris. Histological analysis was shown to be a tool that provides important knowledge about the impact of the parasites on the health of studied marine fish. New records of parasites are presented (Lernanthropus sp. in 0 . chrysurus, Goussia sp. in P. maculatus, L. sultanus in L. synagris) and parasites of importance in Public Health are registered (Anisakis sp., Pseudoterranova sp., Contracaecum sp., and Trypanorhyncha), emphasizing the need for measures to avoid the risk of transmission to consumer. The information contributes to the knowledge about the parasitic fauna of fish and its distribution along the coast of Brazil.

Key words: Anisakiasis; arthropods; coccidian; helminths; zoonosis.

RESUMO - O objetivo deste estudo foi identificar a fauna parasitária, o impacto da relação parasito-hospedeiro e o risco potencial de transmissão de parasitos zoonóticos 
em peixes comercializados na Região Metropolitana de Recife (Nordeste do Brasil). Ectoparasitos e endoparasitos foram coletados em Pseudupeneus maculatus ( $\mathrm{n}=34$ ), Lutjanus synagris $(n=23$ ) e Ocyurus chrysurus $(n=20)$. Os órgãos e/ou tecidos com e sem parasitos foram processados por técnicas histológicas convencionais. Em total, 43 (55,8\%) espécimes estavam parasitados por: Rocinela signata, Lernanthropus sp.; Lernaeolophus sultanus, Goussia sp.; Haliotrema sp.; Raphidascaris (/chthyascaris) sp.; Cucullanus sp.; larvas de Anisakis sp., Pseudoterranova sp., Contracaecum sp. e Trypanorhyncha. Alterações macroscópicas e/ou histopatológicas foram associadas a Lernantrhopus sp. (brânquias) e Pseudoterranova sp. (fígado) em $O$. chrysurus, $R$. signata (brânquias) em P. maculatus e Lernaeolophus sultanus (maxila) de L. synagris. A análise histopatológica demonstrou ser uma ferramenta importante para o conhecimento sobre o impacto dos parasitos na saúde dos peixes estudados. Novos registros de parasitos são apresentados (Lernanthropus sp. em O. chrysurus, Goussia sp. em P. maculatus, L. sultanus em L. synagris) e são registrados parasitos de importância em Saúde Pública (Anisakis sp., Pseudoterranova sp., Contracaecum sp. e Trypanorhyncha), enfatizando a necessidade de medidas para evitar/diminuir o risco de transmissão ao consumidor. Os resultados contribuem para o conhecimento sobre a fauna parasitária de peixes e sua distribuição ao longo da costa do Brasil.

Palavras-chave - Anisaquiose, artrópodes; coccídios; helmintos; zoonose.

\section{INTRODUCTION}

Despite the great diversity of marine fish and their economic importance, studies about the impact of parasites on the health of marine ichthyofauna in Brazil are scarce (Pavanelli et al., 2008). These studies do not exist for the northeastern region of Brazil, where the research already carried out so far has been restricted to the taxonomic identification and occurrence of marine fish parasites (Cavalcanti et al., 2013a, 2013b; Hermida et al., 2014; Alves et al., 2018, 2020; Cardoso et al., 2018).

Several species of fish from reef environments are extensively exploited in the northeast region of Brazil (Frédou and Ferreira, 2005). The reef species Spotted goatfish Pseudupeneus maculatus (Bloch 1793) (Actinopterygii, Mullidae), Lane snapper Lutjanus synagris L. 1798 and Yellowtail snapper Ocyurus chrysurus (Bloch 1791) (Actinopterygii, Lutjanidae) present high trophic diversity, as well as a variety of habitats and lifestyles (Schlacher et al., 2007), thus presenting the highest rates of infection/infestation by parasites (Luque et al., 2004; Kharat and Pimple, 2011; Mohammadi et al., 2012). Pseudupeneus maculatus, L. synagris and 0 . chrysurus are classified as Least Concerned 
(LC), Near Threatened (NT), and Data Deficient (DD), respectively, on the Red List of Threatened Species of the International Union for Conservation of Nature (IUCN, 2019).

Parasites represent a plausible proportion of the world's biodiversity, but are largely neglected (Poulin and Morand, 2004; Goldberg et al., 2016). Parasites can provide important information about ecosystem conditions by establishing close contact between the host and the environment (Kadlec et al., 2003; Luque et al., 2017; Sures et al., 2017). Parasitic infestations/infections are very frequent in fish (Yasuoka and Yusa, 2017), although under natural conditions these animals show few or no clinical signs or abnormalities at the organ and tissue levels (Feist and Longshaw, 2008). Deleterious effects of parasites can result in weight loss, hematological alterations, reduced growth rate (Pavanelli et al., 2008), cause respiratory failure and death (Vasconcelos and TavaresDias, 2014). Histopathological analysis provides information about the effects of parasitic infections/infestations on fish, both in the individual and the population context (Johnson et al., 1993; Feist and Longshaw, 2008), reflecting the health of ecosystems (Roberts, 2012). Besides interfering in fish health, some parasites of these vertebrates have zoonotic potential (Barros et al., 2006; Alves et al., 2020; Debenedetti et al., 2020).

This research aimed to identify parasitic fauna and the impact of the parasite-host relationship, and to assess the potential risk of transmission of zoonotic parasites through the consumption of three species of marine fish marketed in Brazil.

\section{MATERIAL AND METHODS}

\subsection{Fish samples}

Fish captured along the Brazilian of northeast coast were purchased from artisanal fishermen at a fishery unit and in a public market in two cities of Metropolitan Region of Recife (Recife and Itamaracá cities, respectively) in the State of Pernambuco, located in the Northeast Brazil. The fish, chosen at random, were transported in an ice cooler to the laboratory where they were identified, measured (total length) and weighed, then refrigerated at $4^{\circ} \mathrm{C}$ until dissection.

\subsection{Collection, processing, and identification of parasites}

The fish were macroscopically inspected for ectoparasites and/or lesions in the integument. The gill arches were also evaluated for the presence of parasites and/or lesions. The celomatic cavity was opened and the stomach, liver, mesentery, and intestines were systematically examined for parasite collection with the aid of a stereoscopic microscope. Parasites were collected and preserved in alcohol $70 \%$. 
Trematods and cestodes larval stages were stained with hydrochloric carmine, while the nematodes were clarified with lactophenol. The identification of the parasites was based on morphological characteristics (Brusca and France, 1992; Kabata, 1968, 1979; Gibson et al., 2001; Jones et al., 2005; Bray et al., 2008; Anderson et al., 2009). Parasites were deposited in the Coleção Parasitológica do Laboratório de Parasitologia (CPLAPAR: 15001511) da UFRPE.

Prevalence was calculated according to Bush et al. (1997).

\subsection{Macroscopic and histopathological analysis}

Fragments of parasitized and non-parasitized organs/tissues (gill, stomach, intestine, liver, and maxilla), with and without macroscopic lesions, were collected from all animals (77) and processed by conventional histological techniques (Camargo and Martinez, 2007).

\section{RESULTS AND DISCUSSION}

Seventy-seven specimens were studied: 34 P. maculatus, 23 L. synagris and 200. chrysurus. Of these, 43 (55.8\%) were parasitized by ectoparasites and/or endoparasites (helminths and protozoan) collected in the gills, stomach, liver, intestine, and celomatic cavity (Table 1).

Table 1 - Parasites of Ocyurus chrysurus, Pseudupeneus maculatus and Lutjanus synagris from the Brazilian Northeast coast.

\begin{tabular}{ll}
\hline Fish & Parasites and sites of infestation/infection \\
\hline Ocyurus & Rocinela signata (Isopoda, Aegidae) - gill \\
& Lernanthropus sp. (Copepoda, Lernanthropidae) - gill \\
& Pseudoterranova sp., Contracaecum sp. and Anisakis sp. (Nematoda, \\
& Anisakidae) (larvae) - coelomic cavity \\
& Raphidascaris (Ichthyascaris) sp. (Nematoda, Raphidascarididae) - \\
& intestine \\
& Trypanorhyncha (plerocercoid larvae) - coelomic cavity \\
\hline Pseudupeneus & Goussia sp. (Apicomplexa, Barrouxilidae) - liver \\
maculatus & Rocinela signata - gill \\
& Haliotrema sp. (Monogenea, Dactylogiridae) - gill \\
& Pseudoterranova sp. (larvae) - liver (serosa) \\
\hline Lutjanus & Lernaeolophus sultanus (Copepoda, Pennellidae) - maxilla \\
synagris & Cucullanus sp. (Nematoda, Cucullanidae) - intestine \\
\hline
\end{tabular}

Archives of Veterinary Science, v.25, n.4, p.66-79, 2020. 
Of the 20 specimens of $O$. chrysurus, $85.0 \%$ (17/20) were parasitized by endoparasites (85.0\%) and ectoparasites (10.0\%), while the prevalence of L. synagris was 30.4\% (7/23): $17.39 \%$ and $13.0 \%$ by endoparasites and ectoparasites, respectively. Of the 34 specimens of $P$. maculatus, 19 (55.9\%) were parasitized: all animals had endoparasites and $47.4 \%$ had ectoparasites.

The parasites identified were: Rocinela signata Schioedte \& Meinert, 1879 (Isopoda, Aegidae); Lernaeolophus sultanus (Milne Edwards, 1840) (Copepoda, Pennellidae); Lernanthropus sp. (Copepoda, Lernanthropidae); Goussia sp. (Apicomplexa, Barrouxilidae); Anisakis sp., Pseudoterranova sp., and Contracaecum sp. (Nematoda, Anisakidae) (larvae); Haliotrema sp. (Monogenea, Dactylogiridae); cestodes of Trypanorhyncha order (plerocercoid larvae); Raphidascaris (/chthyascaris) sp. (Nematoda, Raphidascarididae) and Cucullanus sp. (Nematoda, Cucullanidae). Parasites and the sites of infestation/infection are presented in table 1.

Parasitic infestations and infections in fish are common, thus the prevalence found was expected. Marine fish exhibit great trophic diversity in aquatic ecosystems, as well as a variety of ways of life and habitats (Schlacher et al., 2007), which favors the dispersion of parasites (Feist and Longshaw, 2008). The parasites are related to aspects of the biology of their hosts, such as diet and migration (Cardoso et al., 2018). For this reason, marine fish are paratenic, intermediate and definitive hosts of a wide range of external and internal parasites (Luque, 2004; Luque et al., 2004, 2017; Cardoso et al., 2018). The diversity of parasites found in the present study is greater than that reported for $P$. maculatus (Cardoso et al., 2018), L. synagris (Cavalcanti et al., 2013a) and O. chrysurus (Alves, 2020) in the waters of the northeast region of Brazil, considering that Cavalcanti et al. (2013a) studied only ectoparasites and Alves et al. (2020) recorded only the occurrence of nematodes Anisakidae and Raphidascarididae.

The gills of $O$. chrysurus parasitized by Lernantrhopus sp. macroscopically presented hemorrhagic areas (Figure 1) and fragility in the gill filaments due to the fixation of the parasite. Hypersecretion of mucus, branchial filament atrophy, inflammation, and congestion were observed (Figure 2). It is important to highlight that all the parasitized animals presented only a single specimen of Lernantrhopus sp. 


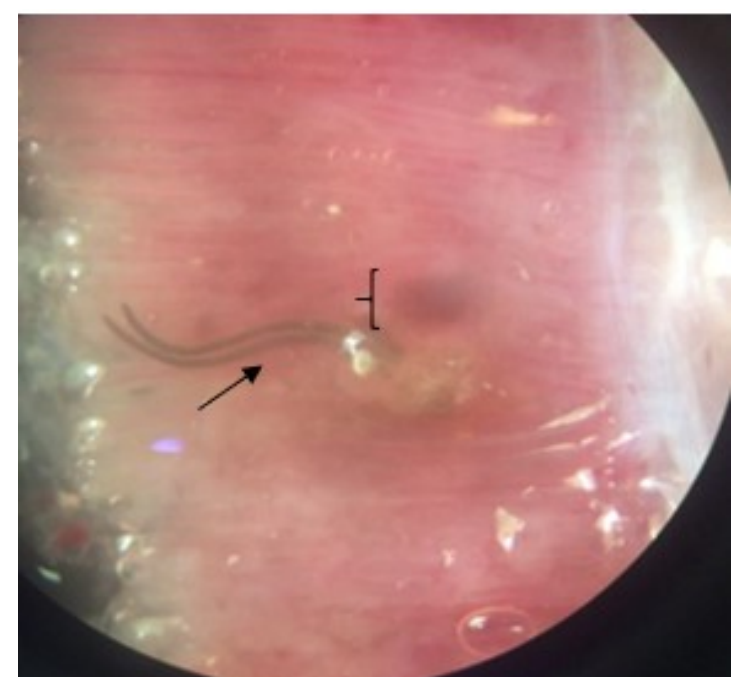

Figure 1 - Hemorrhagic area (key) in the gills of Ocyurus chrysurus infested by Lernantrhopus sp. (Arthropoda, Lernanthropidae) (arrow) attached to the branchial filaments.

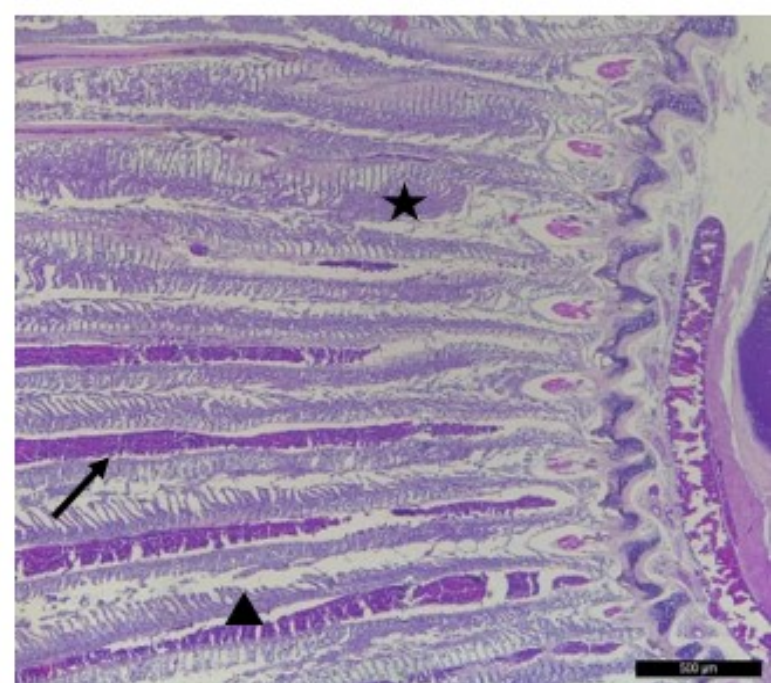

Figure 2 - Gills of Ocyurus chrysurus showing thickening (asterisk), congestion (arrow) and distortion (triangle) of the filaments by infestation of Lernanthropus sp.

Although the genus Lernanthropus is frequently found in fish, and its occurrence has been recorded in lutjanid fish (Cavalcanti et al., 2013a), this is the first report in which macroscopic and histological changes could be observed in the gills of $O$. chrysurus parasitized by this crustacean. The parasitic crustaceans were fixed in the gill cavity, which could lead to changes in respiratory and swimming capacity, loss of weight, and reduction of the growth rate of the affected fish (Pavanelli et al., 2008).

The parasitism by $R$. signata in $O$. chrysurus and $P$. maculatus was associated with mucus hypersecretion and congestion of the gills. The lesions caused by $R$. signata are due to the fixation of this hematophagous parasite (Luque, 2004), resulting in total or partial occlusion of the blood vessels that irrigate the lamellae and provoking a hyperplastic response with an increased secretion of mucus and reduction in the respiratory capacity (Thatcher and Neto, 1994; Pavanelli et al., 2008). In the present study, mucus hypersecretion and congestion of the gills were observed in $P$. maculatus parasitized by $R$. signata. According to Machado et al. (1996), the reduction of the number of gill filaments is a factor in the reduction of the respiratory efficiency of parasitized fish. Some ectoparasites, when in high infestations in the gills, can cause serious lesions that can evolve to respiratory insufficiency and death of the host, as they favor secondary infections caused by bacteria and fungi (Pavanelli et al., 2008; Kharat and Pimple, 2011; Mohammadi et al., 2012; Vasconcelos and Tavares-Dias, 2014). The habit of $P$. maculatus of disturbing the substrate in search of food facilitates infestation in its gills (Dubin, 1982) by isopods and trematodes such as Haliotrema sp., found in the current 
work. In the northeast region of Brazil, H. caraibensis Euzet and Vala, 1976, H. caballeroi Euzet and Vala, 1976, H. golvani Euzet and Vala, 1976, and R. signata have been reported in P. maculatus (Cardoso et al., 2018).

No tissue changes were found in the liver of $P$. maculatus specimens parasitized by coccidian Goussia sp., which was also recorded by Costa and MacKenzie (1994) and Gestal and Azevedo (2005). According to Morrison and Hawkins (1984) the infection by $G$. cruciata (Thélohan, 1892) Labbe, 1896 elicited an intense host reaction and the replacement of hepatic tissue might have stressed the fish, although for Costa and MacKenzie (1994) the hepatic coccidiosis appeared to have been controlled by the host's immune system. There are no reports of parasitism by Goussia sp. in P. maculatus, making this a new record. It is important to highlight that identification of parasitism by this protozoan was only possible due to the histological analysis.

Specimens of L. synagris parasitized by L. sultanus showed increased rostral volume, with consequent maxillary deformity (Figure 3). Histopathological analysis demonstrated a chronic inflammatory reaction, resulting in encapsulation of the parasite, in addition to massive loss of bone structure of the maxilla (Figure 3). This loss of bone architecture justifies the macroscopic aspect of maxillary deformity, representing a threat to the survival of these individuals. Cavalcanti et al. (2013a) recorded the parasitism by Lernaeolophus striatus in L. synagris from northeast region of Brazil. However, although the macroscopic changes identified are similar those reported by Cavalcanti et al. (2013a), the present study describes, for the first time, the histological aspects associated with ectoparasitism by this copepod.

Larvae of Pseudoterranova sp. were fixed in the hepatic serosa and celomatic cavity of $O$. chrysurus, associate with macroscopic lesions, similar to what had been registered by Fontenelle et al. (2013). 


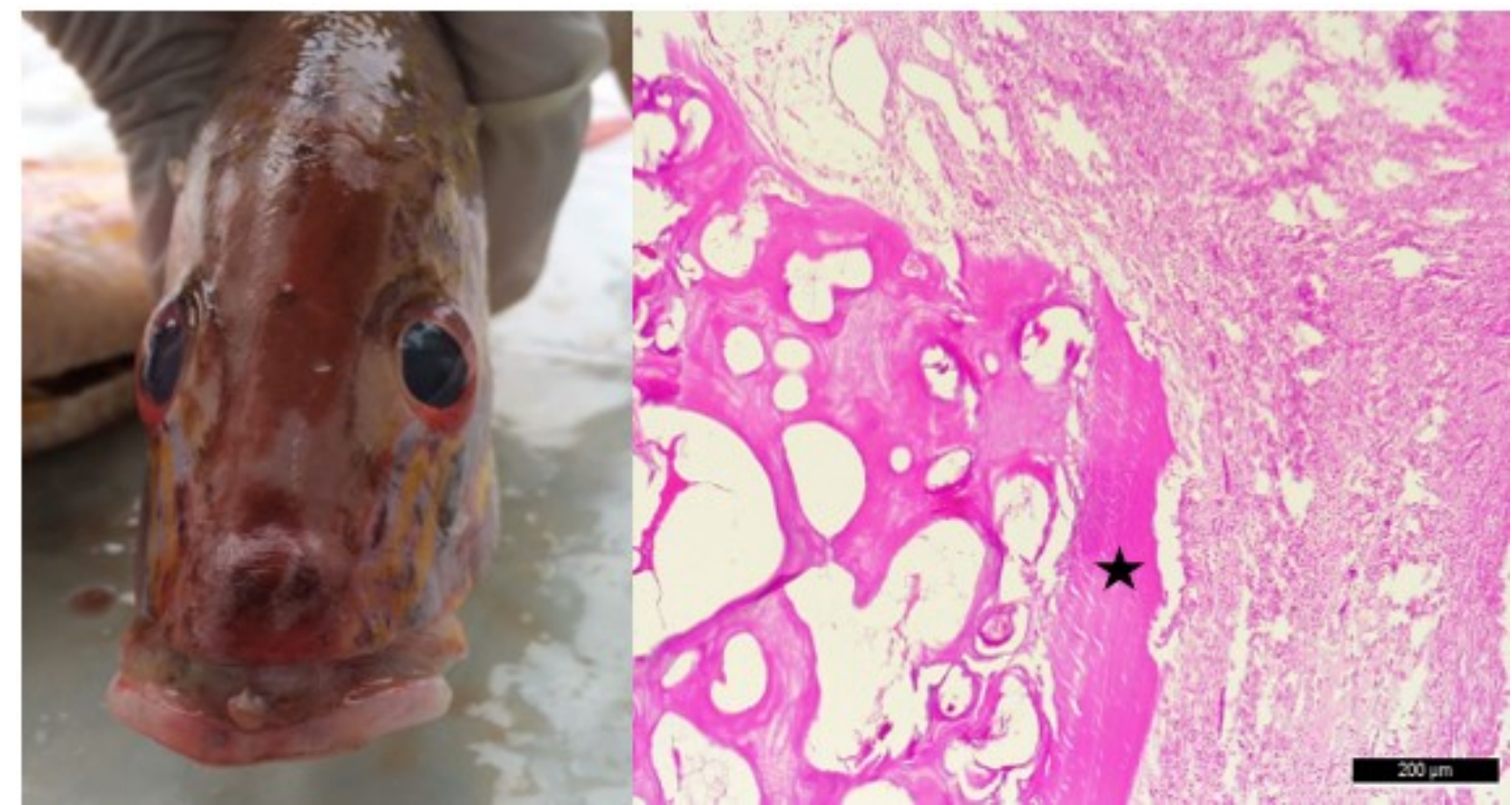

Figure 3 - Lernaeolophus sultanus parasite of Lutjanus synagris. (A) Face deformity; (B) massive loss of bone (asterisk) structure of the maxilla.

In the present study, macroscopic and/or histological alterations found demonstrated the impact of some parasites on the health of the parasitized fish. Besides this, the lesions found also interfere with their commercial value. Histopathological analysis is an important diagnostic tool for detecting the deleterious effects of parasites (Johnson et al., 1993; Feist and Longshaw, 2008), besides being an indicator of the health of the marine ecosystem (Feist and Longshaw, 2008; Roberts, 2012). Fish that are undernourished or exposed to contaminants may become susceptible to deleterious action of parasites and other pathogens (Kubitza, 1999), which compromises their health and conservation. According to Hudson et al. (2002) the parasitism may influence host fitness, even when clinical signs of infection are absent.

Anisakis sp. (larvae), Raphidascaris (/chthyascaris) sp. and plerocercoids of Trypanorhyncha were found in $P$. maculatus and $O$. chrysurus in the current work. These parasites reported had already been registered by Alves et al. $(2018,2020)$ in $O$. chrysurus and L. synagris from the coast of the northeast region of Brazil. Ascaridoid nematodes are among the most abundant helminth parasites of commercially exploited marine fish (Molento et al., 2017; Alves et al., 2020; Debenedetti et al., 2020). The presence of anisakid larvae in the tissues of economically important fish compromises their industrialization process and may have consequences for Public Health due to zoonotic transmission (Molento et al., 2017; Alves et al., 2020; Debenedetti et al., 2020).

Archives of Veterinary Science, v.25, n.4, p.66-79, 2020. 
Humans anisakid infections occur mainly in regions near the coast and is more frequent in countries where fish is eaten raw, undercooked, cold-smoked, or improperly salted (Nawa et al., 2005). Humans who accidentally consume alive parasites can suffer diarrhea, vomiting, and acute abdominal pain (Montoro et al., 1997; Knoff et al., 2007, 2013). Even the ingestion of fish with dead anisakids can cause allergic reactions in sensitive people (Alonso et al., 1999).

Although the anisakids were not found in musculature of fish in the current research, the risks to Public Health cannot be ruled out (Molento et al., 2017; Alves et al., 2020; Debenedetti et al., 2020), mainly due to the immunogenic characteristics of these parasites (Fontenelle et al., 2013). The migration of larvae to the musculature of live or dead fish may occur moments after capture or when fish have been subjected to long periods of storage in boats or markets (Fontenelle et al., 2013).

The cestodes of order Trypanorhyncha have no zoonotic potential. However, larvae present in fish musculature can lead to the production of toxins, causing an allergic reaction in intolerant people (São Clemente et al., 1995). Fish with heavy loads of plerocercoids are rejected during the inspection as they compromise meat hygiene (Alves et al., 2018); and because of their appearance, which can lead to rejection by the consumer (Silva Júnior, 2010).

Dias et al. (2010) and Debenedetti et al. (2020) emphasize the importance of professionals involved in health surveillance, as well as the prior knowledge of fishermen and final consumers about the parasites of fish with zoonotic potential. Health education programs to prevent infection by fish zoonotic parasites should be implemented, especially in coastal cities, such as Recife and Itamaracá cities.

The results contribute to the knowledge about the parasitic fauna of fish and its distribution along the coastline of Brazil.

\section{CONCLUSION}

Some parasites found in this study were associated with macroscopic and histological alterations, which may impact the health of $P$. maculatus, $O$. chrysurus and $L$. synagris. The histopathological analysis demonstrated to be a tool that provides important knowledge about the impact of the parasites on the health of the marine fish of commercial importance. Ascaridoid nematods with importance for Public Health were identified, suggesting the need to implement health education actions to prevent infection by parasites through the consumption of fish. 


\section{INFORMATION NOTES}

This study was approved by Instituto Chico Mendes de Biodiversidade (SISBIO N. 34125-1), the National System for the Management of Genetic Heritage and Traditional Knowledge (SISGEN N. A9 C3 CA5), and Animal Use Ethics Committee of the Universidade Federal Rural de Pernambuco (CEUA-UFRPE N. 003/2018).

\section{ACKNOWLEDGMENT}

This work was supported in part by the Coordenação de Aperfeiçoamento de Pessoal de Nível Superior - Brasil (CAPES) - Finance Code 001, and Conselho Nacional de Desenvolvimento Científico e Tecnológico (CNPq).

\section{REFERENCES}

ALONSO, A.; MORENO-ANCILLO, A.; DASCHNER, A. et al. Dietary assessment in five cases of allergic reactions due to gastroallergic anisakiasis. Allergy, v. 54, p.517-520, 1999. ALVES, A.M.; SOUZA, G.T.R.; TAKEMOTO, R.M. et al. Occurrence of larvae of trypanorhynch cestodes in snappers (Lutjanidae) from northeast Brazil. Brazilian Journal of Veterinary Parasitology, v.27, p.415-419, 2018.

ALVES, A.M.; SOUZA, G.T.R.; TAKEMOTO, R.M. et al. Anisakidae Skrjabin \& Karokhin, 1945 and Raphidascarididae Hartwich, 1954 nematodes in lutjanidae (Pisces: Perciformes) from the Brazilian Northeast Coast. Brazilian Journal of Biology, v.80, p.255-265, 2020.

ANDERSON, R.C.; CHABAUD, A.G.; WILLMOTT, S. Keys to the Nematode Parasites of Vertebrates: Archival volume. CABI Publishing, London. 2009.

BARROS, L.A.; FILHO, J.M.; OLIVEIRA, R.L. Nematóides com potential zoonótico em peixes com importância econômica provenientes do rio Cuiabá. Revista Brasileira de Ciência Veterinária, v. 13, p.55-57, 2006.

BRAY, R.A.; GIBSON, D.I.; JONES, A. Keys to the Trematoda, Volume 3. CABI Publishing, London, 2008.

BRUSCA, R.C.; FRANCE, S.C. The genus Rocinela (Crustacea: Isopoda: Aegidae) in the tropical eastern Pacific. The Zoological Journal of the Linnean Society, v.106, p.231-275, 1992.

BUSH, A.O.; LAFFERTY, K.D.; LOTZ, J.M. et al. Parasitology meets Ecology on its own terms: Margolis et al. revisited. Journal of Parasitology, v.83, p.575-583, 1997.

CAMARGO, M.M.P.; MARTINEZ, C.B.R. Histopathology of gills, kidney and liver of a Neotropical fish caged in an urban stream. Neotropical Ichthyology, v.5, n.3, p.327-336, 2007. 
Parasitic infestations and infections in marine fish (Actinopterygii: Lutjanidae and Mullidae) marketed in Brazil - an animal and human health issue

CARDOSO, L.; LACERDA, A.C.F.; GONÇALVES, E.L.T. et al. Spotted goatfish Pseudupeneus maculatus (Ostheichthyes: Mullidae) and its gill metazoan parasites from the Coast of Pernambuco, Northeast Brazil. Brazilian Journal of Biology, v.78, p.414-420, 2018.

CAVALCANTI, E.T.S.; NASCIMENTO, W.S.; TAKEMOTO, R.M. et al. Ocorrência de crustáceos ectoparasitos no peixe ariocó, Lutjanus synagris (Linnaeus, 1758) nas águas costeiras do Rio Grande do Norte, Brasil. Biota Amazônica, v. 3, p.94-99, $2013 a$.

CAVALCANTI, E.T.S.; ALVES, L.C.; CHELLAPPA, S. Occurrence of endoparasites in the southern red snapper, Lutjanus purpureus (Osteichthyes: Lutjanidae) from the coastal waters of Rio Grande do Norte, Brazil. Journal of Animal Biology, v.4, n.2, p.129-136, 2013b.

COSTA, G.; MACKENZIE, K. Histopathology of Goussia clupearum (Protozoa: Apicomplexa: Coccidia) in some marine fish from Scottish waters. Diseases of Aquatic Organisms, v.18, p.195-202, 1994.

DEBENEDETTI, A.L.; CODES, F.; LAZA, S. et al. Ascaridoid nematodes in horse mackerel, Trachurus trachurus, sold in Spanish supermarkets - Factors able to diminish consumer risk. Fisheries Research, v.230, 2020.

DIAS, F.J.E.; SÃO CLEMENTE, S.C.; KNOFF, M. Nematoides anisaquídeos e cestoides Trypanorhyncha de importância em saúde pública em Aluterus monoceros (Linnaeus, 1758) no Estado do Rio de Janeiro, Brasil. Brazilian Journal of Veterinary Parasitology, v.19, p.94-97, 2010.

DUBIN, R.E. Behavioral interactions between Caribbean reef fish and eels (Muraenidae and Ophichthidae). Copeia, v. 1, p.229-232, 1982.

FEIST, S.W.; LONGSHAW, M. Histopathology of fish parasite infections - importance for populations. Journal of Fish Biology, v.73, p.2143-2160, 2008.

FONTENELLE, G.; KNOFF, M.; FELIZARDO, N.N. et al. Nematodes of zoonotic importance in Cynoscion guatucupa (Pisces) in the state of Rio de Janeiro. Brazilian Journal of Veterinary Parasitology, v.22, p.281-284, 2013.

FRÉDOU, T.; FERREIRA, B.P. Bathymetric trends of northeastern Brazilian snappers (Pisces, Lutjanidae): implications for the reef fishery dynamic. Brazilian Archives of Biology and Technology, v.48, p.787-800, 2005.

GESTAL, C.; AZEVEDO, C. Ultrastructure of Goussia cruciata (Apicomplexa: Coccidia) infecting the liver of horse mackerel, Trachurus trachurus (L.), from Ibero-Atlantic waters. Journal of Fish Diseases, v.28, p.125-32, 2005.

GIBSON, D.I.; BRAY, R.A.; JONES, A. Keys to the Trematode, Volume 1. CABI Publishing, London. 2001. 
GOLDBERG, S.R.; BURSEY, C.R.; KRAUS, F. Helminths of 13 species of microhylid frogs (Anura: Microhylidae) from Papua New Guinea. Journal of Natural History, v.50, p.20052020, 2016.

HERMIDA, M.; CARVALHO, B.F.L.; CRUZ, C. Parasites of the Mutton Snapper Lutjanus analis (Perciformes: Lutjanidae) in Alagoas. Brazilian Journal of Veterinary Parasitology, v.23, p.241-243, 2014.

HUDSON, P., RIZZOLI, A., GRENFELL, B. et al. The ecology of wildlife disease. Oxford University Press. 2002.

IUCN. International Union for Conservation of Nature. https://www.iucnredlist.org> Accesso em: 2/11/2019.

JOHNSON, L.L.; STEHR, C.M.; OLSON, O.P. et al. Chemical contaminants and hepatic lesions in winter flounder (Pleuronectes americanus) from the Northeast Coast of the United States. Environmental Science and Technology, v.27, p.2759-2771, 1993.

JONES, A.; BRAY, R.A.; GIBSON, D.I. Keys to the Trematoda: Volume 2. CABI Publishing, London. 2005.

KABATA, Z. The appendages of Lernaeolophus sultanus ( $H$. Milne Edwards, 1840) (Lernaeoceridae). Crustaceana, Supplement 1, p.103-111, 1968.

KABATA, Z. Parasitic Copepoda of Bristish Fishes. The Ray Society, London. 1979.

KADLEC, D.; SIMKOVÁ, A.; JARKOSVKÝ, J. et al. Parasite communities of freshwater fish under flood conditions. Parasitology Research, v.89, p.272-283, 2003.

KHARAT, D.S.S.; PIMPLE, N.S. Histopathological studies of monogenean parasite Diplozoan paradoxum (Nordmann,1832) in the gills of freshwater fish Osteobrama vigorsii (Sykes) from Nira river, Bhor district (Maharashtra), India. Indian Journal Applied Research, v.3, p.550-552, 2011.

KNOFF, M.; CARMONA, S.; GONÇALVES, M. et al. Anisakidae parasitos de congro-rosa, Genypterus brasiliensis Regan, 1903 comercializados no estado do Rio de Janeiro, Brasil de interesse na saúde pública. Parasitología Latinoamericana, v.62, 2007.

KNOFF, M.; SÃO CLEMENTE, S.C.; KARLING, L.C. et al. Helmintos de potential zoonótico. In: PAVANELLI, G.C.; TAKEMOTO, R.M.; EIRAS, J.C. Parasitologia de peixes de água doce do Brasil. EDUEM, Maringá, 2013, p.17-35.

KUBITZA, F. Principais parasitoses e doenças dos peixes cultivados. 3 ed. Degaspari: Piracicaba. 1999.

LUQUE, J.L. Biologia, epidemiologia e controle de parasitos de peixes. Brazilian Journal of Veterinary Parasitology, v.13, p.161-165, 2004. 
LUQUE, J.L.; MOUILLOT, D.; POULIN. R. Parasite biodiversity and its determinants in coastal marine teleost fishes of Brazil. Parasitology, v.128, p.671-682, 2004.

LUQUE, J.L.; PEREIRA, F.B.; ALVES, P.V. et al. Helminth parasites of South American fishes: current status and characterization as a model for studies of biodiversity. Journal of Helminthology, v.91, p.150-164, 2017.

MACHADO, M.H.; PAVANELLI, G.C.; TAKEMOTO, R.M. Structure and diversity of endoparasitic infracommunities and the trophic level of Pseudoplatystoma corruscans and Schizodon borelli (Osteichthyes) of the high Paraná river. Memórias do Instituto Oswaldo Cruz, v.91, p.441-448, 1996.

MOHAMMADI, F.; MOUSAVI, S.M.; REZAIE, A. Histopathological study of parasitic infestation of skin and gill on oscar (Astronotus ocellatus) and discus (Symphysodon discus). AACL Bioflux, v.5, p.88-93, 2012.

MOLENTO, M.B.; ALMEIDA, J.C.R.; HAMANN, W. et al. Análise do parasitismo por nematoides da família Anisakidae em peixes marinhos provenientes do litoral paranaense, Brasil. Archives of Veterinary Science, v.2, p.64-70, 2017.

MONTORO, A.; PERTEGUER, M.J.; CHIVATO, T. et al. Recidivous acute urticaria caused by Anisakis simplex. Allergy, v.52, p.985-991, 1997.

MOREIRA, P.S. Species of marine isopoda (crustacea, peracarida) from southern Brazil. Boletim do Instituto Oceanográfico, v.21, p.163-179. 1972.

MORRISON, C.M.; HAWKINS, W.E. Coccidians in the liver and testis of the herring Clupea harengus L. Canadian Journal of Zoology, v.62, p.480-493, 1984.

NAWA, Y.; HATZ, C.; BLUM, J. Sushi delights and parasites: the risk of fishborne and foodborne parasitic zoonoses in Asia. Clinical Infectious Diseases, v.41, p.1297-1303, 2005.

PAVANELLI, G.C.; EIRAS, J.C.; TAKEMOTO, R.M. Doenças de peixes: profilaxia, diagnóstico e tratamento. 3 ed. EDUEM: Maringá. 2008.

POULIN, R.; MORAND, S. Parasite biodiversity. Smithsonian Institution, Washington D.C. 2004.

ROBERTS, R.J. Fish Pathology. 4 ed. Wiley-Blackwell, Oxford. 2012.

SÃO CLEMENTE, S.C.; LIMA, F.C.; UCHOA, C.M. Parasitos de Balistes vetula (L.) e sua importância na inspeção do pescado. Revista Brasileira de Ciência Veterinária, v.2, p.3941, 1995.

SCHLACHER, T.A.; MONDON, J.A.; CONNOLLY, R.M. Estuarine fish health assessment: evidence of wastewater impacts based on nitrogen isotopes and histopathology. Marine Pollution Bulletin, v.54, p.1762-1776, 2007. 
SILVA JÚNIOR, A.C. Parasitismo por cestoides da ordem Trypanorhyncha na musculatura de Plagioscion squamosissimus - pescada branca (Perciforme: Scianidae), comercializados em Macapá, AP. Ciência Animal Brasileira, v. 11, p.738-742, 2010.

SURES, B.; NACHEV, M.; SELBACH, C. et al. Parasite responses to pollution: what we know and where we go in 'Environmental Parasitology.' Parasitology and Vectors v.10, p.65, 2017.

THATCHER, V.E.; NETO, J.B. Diagnóstico, prevenção e tratamento das enfermidades de peixes neotropicais de água doce. Revista Brasileira de Parasitologia Veterinária, v.16, p.111-128, 1994.

VASCONCELOS, H.C.G.; TAVARES-DIAS, M. Influência da sazonalidade na infestação de Ergasilus turucuyus (Copepoda: Ergasilidae) em Acestrorhynchus falcirostris e Hemiodus unimaculatus (Osteichthyes: Characiformes) do Reservatório Coaracy Nunes, Estado do Amapá, Brasil. Biota Amazônica, v.4, p.106-110, 2014.

YASUOKA, N.; YUSA, Y. Effects of a crustacean parasite and hyperparasite on the Japanese spiny oyster Saccostrea kegaki. Marine Biology, v.164, p.217, 2017. 